\title{
Mineral Utilization in Rams Fed Ration Supplemented with Different Levels of Chromium, Calcium, and Cation-Anion Balances
}

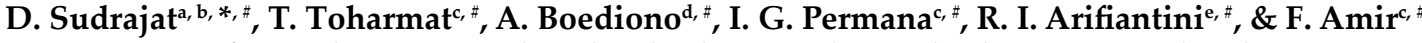 \\ aDepartment of Animal Nutrition and Feed Technology, Graduate School, Bogor Agricultural University \\ bDepartment of Animal Science, Faculty of Agribusiness and Food Technology, University of Djuanda \\ Jln. Tol Ciawi No. 1, Bogor 16720, Indonesia \\ 'Department of Animal Nutrition and Feed Technology, Faculty of Animal Science, Bogor Agricultural University \\ dDepartment of Veterinary Clinic, Reproduction, and Pathology, Faculty of Veterinary Science, \\ Bogor Agricultural University \\ eDepartment of Anatomy, Physiology, and Pharmacology, Faculty of Veterinary Science, \\ Bogor Agricultural University \\ \#Jln. Agatis, Kampus IPB Darmaga Bogor 16680, Indonesia \\ (Received 04-05-2011; accepted 18-10-2011)
}

\begin{abstract}
ABSTRAK
Kromium (Cr) adalah mineral penting bagi ternak ruminansia. Metabolisme dan interaksi mineral $\mathrm{Cr}$ belum banyak diketahui. Penelitian ini dilakukan untuk mengkaji utilisasi mineral dan pertumbuhan domba garut yang diberi mineral $\mathrm{Cr}$, $\mathrm{Ca}$, dan neraca kation anion ransum (NKAR) berbeda. Perlakuan ransum adalah R0 (ransum dengan NKAR+14); R1 (Ransum dengan NKAR+14 + Cr 3ppm), R2 (Ransum dengan NKAR 0 + Ca); R3 (Ransum dengan NKAR 0 + Cr 3 ppm + Ca). Rancangan penelitian adalah rancangan kelompok menggunakan 24 ekor domba garut jantan berumur 1,5-2 tahun. Suplementasi $\mathrm{Cr}$ dalam ransum yang mengandung Ca tidak mempengaruhi konsumsi ransum, pertambahan bobot badan, dan kecernaan bahan kering ransum, tetapi menurunkan penyerapan $\mathrm{Cr}$ dan Ca pada ransum rendah $\mathrm{Ca}$. Suplementasi $\mathrm{Cr}$ tidak berpengaruh terhadap status $\mathrm{Cr}, \mathrm{Ca}, \mathrm{Zn}$, dan $\mathrm{Mg}$ dalam darah dan semen. Tingkat konsumsi $\mathrm{Cr}$ berhubungan negatif dengan tingkat penyerapan Cr dan berhubungan positif dengan kadar $\mathrm{Cr}$ darah. Terdapat hubungan positif antara konsumsi Ca dengan tingkat penyerapan $\mathrm{Ca}$ dan $\mathrm{Mg}$ juga dengan kadar $\mathrm{Ca}$ dan $\mathrm{Zn}$ darah. Konsumsi $\mathrm{Cr}$ dan $\mathrm{Ca}$ tidak berhubungan dengan kadar $\mathrm{Cr}$ dan Ca semen.
\end{abstract}

Kata kunci: kromium, kalsium, neraca kation-anion, domba garut

\section{ABSTRACT}

Chromium $(\mathrm{Cr})$ is an essential mineral for ruminants. Its metabolism and interactions with other minerals has not been widely known. This experiment was designed to evaluate the utilization of minerals and growth of Garut ram fed ration supplemented with $\mathrm{Cr}$ and different Dietary Cation Anion Balance (DCAB) and Ca level. Dietary treatments, namely: R0 (Ration with DCAB+14); R1 (Ration with DCAB+14 + Cr 3ppm,); R2 (Ration with DCAB 0 + Ca); R3 (Ration with DCAB 0 + Cr 3 $\mathrm{ppm}+\mathrm{Ca}$ ), were allocated in twenty four of 1.5-2 years old Garut rams in a randomized block design. The results showed that $\mathrm{Cr}$ supplementation in rations containing different levels of $\mathrm{Ca}$ did not affect feed intake, body weight gain, and dry matter digestibility, but reduced the absorption of $\mathrm{Cr}$ and $\mathrm{Ca}$ of the low Ca diet. Supplementation of $\mathrm{Cr}$ had no effect on $\mathrm{Cr}, \mathrm{Ca}, \mathrm{Zn}$, and $\mathrm{Mg}$ status in blood and semen of the rams. Level of $\mathrm{Cr}$ intake had negative correlation with $\mathrm{Ca}$ absorption and positive correlation with blood $\mathrm{Cr}$ levels. There is a positive relationship between level of $\mathrm{Ca}$ intake with $\mathrm{Ca}$ and $\mathrm{Mg}$ absorption and blood $\mathrm{Ca}$ and $\mathrm{Zn}$ levels. Intake of $\mathrm{Cr}$ and $\mathrm{Ca}$ was not related to the semen $\mathrm{Cr}$ and Ca levels.

Key words: chromium, calcium, kation-anion balance, Garut rams

* Corresponding author:

e-mail: den_sudrajat@yahoo.co.id 


\section{INTRODUCTION}

The benefits of $\mathrm{Cr}$ have been known for 50 years. However, the dietary requirements of livestock for chromium have not been defined (Suttle, 2010). Chromium in the form of glucose tolerance factor (GTF) is known to play a role in blood flow by increasing the potential of insulin activity and therefore the entry of glucose (NRC, 2001) required in the metabolism of fat and protein synthesis in cells (Pollard et al., 2001; Suttle, 2010). The possible roles of $\mathrm{Cr}$ include its participation in maintaining the stability of the structure of proteins and nucleic acids and playing a role in reproduction because it is required for growth and development of the fetus (Lindemann, 2004; Pechova \& Pavlata, 2007).

Chromium deficiency depresses nucleic acid synthesis and decreases spermatozoa count and fertility in rodents (Anderson \& Polansky, 1981). On the other hand, high levels of $\mathrm{Cr}$ reduce the production of spermatozoa (Skandhan et al., 2005), alter semen quality and reproductive hormones as well as decrease the number and morphology of normal spermatozoa (Kumar, 2008).

Minerals interact each other which result in toxicity or deficiency. Excessive nutrient levels can be diagnosed and prevented, otherwise deficiency is often difficult to be controlled and anticipated because an element has different functional roles. Mineral interactions occur in the digestive tract, so that the consumption of minerals simultaneously leads to competition in absorption. Intake of high $\mathrm{Cr}$ reduces retention of $\mathrm{Co}, \mathrm{Fe}$, and $\mathrm{Mn}$ (Luseba, 2005; Gropper et al., 2009). In contrast, reduced absorption of $\mathrm{Cr}$ may occur if $\mathrm{Ca}$ is given in the form of calcium carbonate and antacids (Mateljan, 2010), high dietary Zn, V and Fe (Krejpcio, 2001), and Cr bound to phytic acid (Krejpcio, 2001; Mateljan, 2010).

Cations $\left(\mathrm{Na}^{+}\right.$and $\left.\mathrm{K}^{+}\right)$and anions $\left(\mathrm{Cl}^{-}\right.$and $\left.\mathrm{SO}_{4}^{-}\right)$have a major influence on metabolic processes in the body and acid-base values. Cation and anion levels are expressed by dietary cation-anion balance (DCAB) (Chan et al., 2005). Values of DCAB affect ration consumption, Ca metabolism (Tauriainen, 2001), Mg levels in plasma and semen (Hidayat, 2009) and amino acid metabolism (Mowat, 2008).

The objective of this study was to evaluate the utilization of minerals and growth of Garut rams fed ration supplemented with $\mathrm{Cr}$ and different dietary cation anion balance (DCAB) and Ca level.

\section{MATERIALS AND METHODS}

\section{Feeding Experiment}

Feed consisted of corn hay, yellow corn, rice bran, coconut meal, soybean meal, corn oil, urea, $\mathrm{ZnSO}_{4^{\prime}}$ $\mathrm{CaCO}_{3}$, and $\mathrm{CaCl}_{2}$. Chromium was given in the form of organic $\mathrm{Cr}$ resulted from yeast fermentation on soybean substrate. Rations were formulated isoprotein and isocalory according to the recommendations of NRC (1985) (Table 1). Dietary treatments, namely: R0 (ration with $\mathrm{DCAB}+14$ ); R1 (Ration with $\mathrm{DCAB}+14+\mathrm{Cr}$ ); R2 (Ration with $\mathrm{DCAB} 0+\mathrm{Ca}$ ); R3 (Ration with $\mathrm{DCAB} 0+\mathrm{Cr}+\mathrm{Ca}$ ), were allocated into twenty four 1.5-2 years old Garut rams in a randomized block design.

\section{Animal Rearing Experiment}

Forty-four rams (mean 1.5 years old with body weight $32.02 \pm 3.71 \mathrm{~kg}$ ) were used in this experiment. Ram was grouped according to their body weight. Rams were were maintained for 3 months in individual cages in the Laboratory of Meat and Work Animal Nutrition, Faculty of Animal Science, Bogor Agricultural University.

In the first 21 days, rams were adapted to the conditions of management, the cages environment and feedstuffs. Furthermore, on day 22 to day 96 rams were fed dietary treatment. During the experimental, rams were fed at around 7:00 and 14:00 o' clock. Drinking water was provided ad libitum.

\section{Sampling and Analysis}

A total fecal collection to measure the value of nutrient digestibility and mineral absorption were performed on day 35 to day 42 . Feces collected as much

Table 1. Ingredient and chemical composition of the rations

\begin{tabular}{lcccc}
\hline \multirow{2}{*}{ Ingredient/nutrient } & \multicolumn{5}{c}{ Ration } \\
\cline { 2 - 5 } & $\mathrm{R} 0$ & $\mathrm{R} 1$ & $\mathrm{R} 2$ & $\mathrm{R} 3$ \\
\hline Feed composition (\% of DM basal ration) & & \\
Corn straw & 35 & 35 & 35 & 35 \\
Rice bran & 21.5 & 21.5 & 21.5 & 21.5 \\
Yellow corn & 19.65 & 19.65 & 19.65 & 19.65 \\
Soybean meal & 13.6 & 13.6 & 13.6 & 13.6 \\
Coconut cake meal & 8 & 8 & 8 & 8 \\
Urea & 0.25 & 0.25 & 0.25 & 0.25 \\
Corn oil & 2 & 2 & 2 & 2 \\
Content of nutrient (\%) & & & & \\
Dry matter & 90.31 & 90.31 & 90.41 & 90.41 \\
Ash & 7.4 & 7.4 & 8.1 & 8.1 \\
Crude protein & 13.5 & 13.5 & 13.5 & 13.5 \\
Crude fat & 7.5 & 7.5 & 7.7 & 7.5 \\
Crude fiber & 17.5 & 17.5 & 17.5 & 17.5 \\
Gross energy & 3263 & 3263 & 3263 & 3263 \\
(Kcal/kg) & & & & \\
Content of mineral ${ }^{2}$ & & & & \\
Cr (ppm) & 5.59 & 8.59 & 5.59 & 8.59 \\
Ca (\%) & 0.21 & 0.21 & 0.42 & 0.42 \\
Zn (ppm) & 139.12 & 139.12 & 139.12 & 139.12 \\
Mg (\%) & 1.46 & 1.46 & 1.46 & 1.46 \\
DCAB (meq) & 14 & 14 & 0 & 0 \\
\hline
\end{tabular}

Note: $\mathrm{R} 0=$ Basal ration, $\mathrm{R} 1=\mathrm{R} 0+\mathrm{Cr}, \mathrm{R} 2=\mathrm{R} 0+\mathrm{Ca}, \mathrm{R} 3=\mathrm{R} 2+\mathrm{Cr}$ (addition of minerals on the R1, R2, and R3 by calculation).

${ }^{1}$ The results of proximate analysis laboratory in PAU (2008) and Laboratorium of Nutrition and Feed Technology, Faculty of Animal Science, Bogor Agricultural University (2009); ${ }^{2}$ The results of mineral analysis in Dairy Nutrition Laboratory, Faculty of Animal Science, Bogor Agricultural University and Balitnak (2009) 
as $10 \%$ for analysis of mineral content. Consumption of each ram was measured daily and rams were weighed every week. Feeding treatments were continued for 49 days (one period of spermatogenesis). On day 50 was performed collection of rams semen, and then levels of the mineral in semen were analyzed. On day 53 blood sampling was done to determine the mineral status of the blood. Analysis of dry matter and nutrient content of feed and feces were done using the method of proximate (AOAC, 2002). Minerals analysis (Cr, Mg, Zn, and Ca) of feed, feces, blood, and semen were done by wet ashes and measured by atomic absorption spectrophotometer (AAS) Varian Spectra AA220 series (Carry \& Allaway, 1971). The data obtained were tabulated and analyzed by analysis of variance. Analysis followed by Tukey test to determine differences between treatments.

\section{RESULTS AND DISCUSSION}

\section{Feed Intake and Average Daily Gain of Garut Ram}

Supplementation of $3 \mathrm{ppm} \mathrm{Cr}$ in the ration did not affect dry matter intake and average daily gain Garut sheep males (Table 2, Figure 1 \& 2). Previous research reports showed that $\mathrm{Cr}$ supplementation of $0.3 \mathrm{ppm}$ in rations containing 707-858 $\mathrm{mg} \mathrm{Cr} / \mathrm{kg}$ increased feed intake and average daily gain of transport-stressed lamb (Kraidees et al., 2009) and not stressed lamb (Yan et al., 2008). While the study of Mathius et al., (2005), 4 ppm Cr supplementation in sheep rations did not affect consumption and average daily gain. Chromium content of the ration in this experiment is thought to be sufficient and still in the safe range so it did not affect the consumption of rations and growth. Chromium needs to be increased in conditions such as motoric activity or stress, transport, and infection when the loss of $\mathrm{Cr}$ in the urine increases (NRC, 2007).

\section{Minerals Absorption in Male Sheep Rations}

Chromium supplementation in lamb rations significantly decreased absorption of $\mathrm{Cr}$ (Table 3). Absorption values at R1 and R3 rations supplemented 3 ppm $\mathrm{Cr}$ decreased $19.25 \%$ and $30.01 \%$ compared to supplemented rations without $\mathrm{Cr}$. Chromium absorption in the digestive tract is affected by the form of $\mathrm{Cr}$ ration. Absorption of inorganic $\mathrm{Cr}$ is lower than the $\mathrm{Cr}$ binding with amino acids or other ligands that bind to inorganic Cr (Gropper et al., 2009). Impairment of absorption of $\mathrm{Cr}$ on rations $\mathrm{R} 1$ and $\mathrm{R} 3$ indicated that endogenous $\mathrm{Cr}$

Tabel 2. Dry matter intake (DM), $\mathrm{Cr}, \mathrm{Ca}, \mathrm{Zn}, \mathrm{Mg}$, and average daily gain (ADG) of Garut ram

\begin{tabular}{|c|c|c|c|c|}
\hline \multirow{2}{*}{ Variables } & \multicolumn{4}{|c|}{ Ration } \\
\hline & R0 & R1 & $\mathrm{R} 2$ & $\mathrm{R} 3$ \\
\hline \multicolumn{5}{|l|}{ Intake } \\
\hline $\mathrm{DM}(\mathrm{g} / \mathrm{d})$ & $873.00 \pm 176.00$ & $865.00 \pm 145.00$ & $922.00 \pm 167.00$ & $1,088.00 \pm 167.00$ \\
\hline $\mathrm{DM}(\%$ of $\mathrm{BW})$ & $2.64 \pm \quad 0.40$ & $2.63 \pm \quad 0.45$ & $2.83 \pm \quad 0.29$ & $3.02 \pm \quad 0.59$ \\
\hline $\mathrm{Cr}(\mathrm{mg})$ & $4.16 \pm \quad 0.80^{\mathrm{a}}$ & $6.63 \pm 1.18^{\mathrm{b}}$ & $4.56 \pm \quad 0.80^{\mathrm{a}}$ & $7.97 \pm \quad 1.50^{b}$ \\
\hline $\mathrm{Ca}(\mathrm{g})$ & $1.57 \pm \quad 0.30^{\mathrm{a}}$ & $1.63 \pm \quad 0.29^{\mathrm{a}}$ & $3.46 \pm \quad 0.61^{\mathrm{b}}$ & $3.93 \pm \quad 0.74^{b}$ \\
\hline $\mathrm{Zn}(\mathrm{mg})$ & $103.61 \pm 19.86$ & $107.50 \pm 19.21$ & $113.48 \pm 19.95$ & $129.12 \pm 22.33$ \\
\hline $\operatorname{Mg}(g)$ & $10.84 \pm 2.08$ & $11.25 \pm \quad 2.01$ & $11.88 \pm \quad 2.09$ & $13.52 \pm \quad 2.55$ \\
\hline ADG (g) & $114.00 \pm 70.00$ & $102.00 \pm 32.00$ & $116.00 \pm 25.00$ & $109.00 \pm 64.00$ \\
\hline
\end{tabular}

Means in the same row with different superscript differ significantly $(\mathrm{P}<0.05)$.

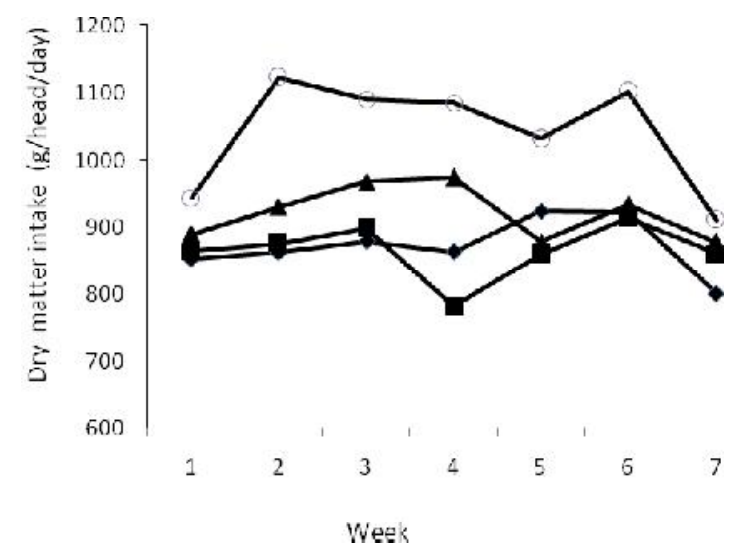

Figure 1. Dry matter intake of Garut ram for seven weeks fed R0 $(-\bullet-)$, R1 (-ш-), R2 (- - -), and R3 (-o-).

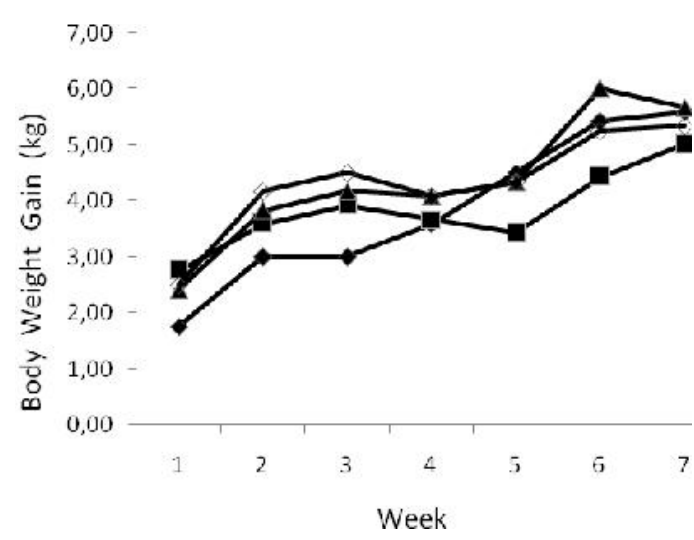

Figure 2. Body weight gain of Garut ram for seven weeks fed R0

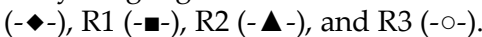


in the basal feed (R0) is more easily absorbed than $\mathrm{Cr}$ of fermented products. Although $\mathrm{Cr}$ of ration R1 and R3 comes from the fermentation by fungi which is a method of organic $\mathrm{Cr}$ production, but most of $\mathrm{Cr}$ are still in the form of inorganic $\mathrm{Cr}$ as only $12.01 \%$ of $\mathrm{Cr}$ in the form of the protein (Agustin et al., 2010). Chromium mineral in the ration $\mathrm{R} 0$ and $\mathrm{R} 2$ is a natural $\mathrm{Cr}$ feed in organic form (Vincent, 1999). Absorption of inorganic Cr is only 2\%-3\% (Anderson \& Kozlovsky, 1985) and lower than the organic form of about $10 \%-25 \%$ (NRC, 1997). There was a negative relationship between consumption of $\mathrm{Cr}$ with absorption of $\mathrm{Cr}(\mathrm{R}=0.58)$ (Table 4$)$. In addition, higher consumption of $\mathrm{Cr}$ caused lower absorption of $\mathrm{Cr}$ (Anderson \& Kozlovsky, 1985).

Chromium supplementation in the ration reduced the absorption of Ca at low Ca ration (R1). This means that $\mathrm{Cr}$ supplementation on low $\mathrm{Ca}$ rations exacerbated Ca absorption. While on R2 and R3 rations contain enough $\mathrm{Ca}$, Cr supplementation did not affect absorption of $\mathrm{Ca}$. Absorption of $\mathrm{Ca}$ in the digestive tract requires Calbindin which is a Ca-binding protein $(\mathrm{CaBP})$ to enter into the membrane of the digestive tract. Molecule of CaBP has a high affinity for Ca (Georgievskii, 1982). However, a higher affinity to the other minerals affects the bond between $\mathrm{Ca}$ and Calbindin in the intestine (Suttle, 2010). Based on the period of the periodic table of elements, $\mathrm{Cr}$ has greater affinity than $\mathrm{Ca}$, so that $\mathrm{Cr}$ is easier bound to the protein compounds such as CaBP. In addition there are similarities between the mechanism of action and structure of Calbindin and low molecularweight chromium binding substance (LMWCr) (Vincent, 1999) which would lead to competition between minerals (Lehninger et al., 2004). It is therefore supposed that low absorption of $\mathrm{Ca}$ in $\mathrm{R} 1$ due to the competition between the two minerals to bind CaBP.

Ca absorption of R2 and R3 ration was higher than Ca absorption of R0 and R1 ration. This was also caused by DCAB differences. The Low DCAB in rations $\mathrm{R} 2$ and R3 stimulates increased $\mathrm{Ca}$ absorption from the gut. According to Ramberg et al., (2009), DCAB reduction enhances renal production of $1.25-(\mathrm{OH})_{2} \mathrm{D}_{3}$, the active metabolite of vitamin $\mathrm{D}$, increases the responsiveness of target tissue receptors to $1,25-(\mathrm{OH})_{2} \mathrm{D}_{3}$ and increases both the efficiency of $\mathrm{Ca}$ absorption and mobilization of calcium from bone.

Absorption of Zn was not affected by $\mathrm{Cr}$ supplementation at different levels of Ca rations. Zinc absorption of sheep rations was in a fairly narrow range of between 30.21 to $35.58 \mathrm{ppm}$. The value of mineral absorption of $\mathrm{Mg}$ in the ration of sheep was not influenced by $\mathrm{Cr}$ supplementation at different levels of Ca. But there was a negative relationship between consumption of Ca with $\mathrm{Mg}$ absorption values $(\mathrm{R}=0.43, \mathrm{P}<0.05)$. High levels of $\mathrm{Ca}$ intake may reduce $\mathrm{Mg}$ absorption in the digestive tract (Gropper et al., 2009).

The value of $\mathrm{Cr}$ mineral absorption (Table 4) had a negative relationship with the consumption of $\mathrm{Cr}(\mathrm{R}=$ 0.58). The higher $\mathrm{Cr}$ consumption reduced the absorption of $\mathrm{Cr}$. Any increase in one unit of $\mathrm{Cr}$ consumption will reduce absorption of $\mathrm{Cr} 6.4 \%$. Blood $\mathrm{Cr}$ values also had a positive relationship with consumption of $\mathrm{Cr}$, the higher the consumption of $\mathrm{Cr}$ it increased blood $\mathrm{Cr}$, while $\mathrm{Cr}$ consumption was not associated with levels of $\mathrm{Cr}$ in semen. The value of $\mathrm{Ca}$ absorption related to

Table 3. Means absorption of $\mathrm{Cr}, \mathrm{Ca}, \mathrm{Zn}$, and $\mathrm{Mg}$ Garut ram rations (\%)

\begin{tabular}{ccccc}
\hline \multirow{2}{*}{ Variables } & \multicolumn{3}{c}{ Ration } \\
\cline { 2 - 5 } & R0 & R1 & R2 & R3 \\
\hline Cr & $68.52 \pm 9.86^{\mathrm{a}}$ & $19.25 \pm 7.72^{\mathrm{b}}$ & $58.03 \pm 12.34^{\mathrm{a}}$ & $30.01 \pm 16.31^{\mathrm{b}}$ \\
$\mathrm{Ca}$ & $78.11 \pm 5.93^{\mathrm{a}}$ & $70.10 \pm 10.24^{\mathrm{b}}$ & $82.53 \pm 8.09^{\mathrm{a}}$ & $84.16 \pm 5.54^{\mathrm{a}}$ \\
$\mathrm{Zn}$ & $32.47 \pm 15.44$ & $30.21 \pm 8.37$ & $35.58 \pm 7.65$ & $31.17 \pm 9.84$ \\
$\mathrm{Mg}$ & $73.05 \pm 7.95$ & $71.25 \pm 11.89$ & $65.82 \pm 5.44$ & $61.75 \pm 6.59$ \\
\hline
\end{tabular}

Means in the same row with different superscript differ significantly $(\mathrm{P}<0.05)$.

Table 4. Correlation and regression of mineral intake with absorption and mineral status in Garut ram blood and semen

\begin{tabular}{lccc}
\hline \multicolumn{1}{c}{ Variables } & $\mathrm{R}$ & Significance & Regression equation \\
\hline Cr intake-Absorption of Cr & -0.58 & 0.080 & $\mathrm{Y}=84.691-6.390 \mathrm{X}$ \\
Cr intake-Cr blood & 0.42 & 0.067 & $\mathrm{Y}=0.022+0.016 \mathrm{X}$ \\
Ca intake-Absorption of Ca & 0.48 & 0.020 & $\mathrm{Y}=69.46+3.58 \mathrm{X}$ \\
Ca intake-Absorption of Mg & -0.45 & 0.030 & $\mathrm{Y}=77.01-3.41 \mathrm{X}$ \\
Ca intake-Ca blood & 0.56 & 0.005 & $\mathrm{Y}=30.30+2.84 \mathrm{X}$ \\
Ca intake-Zn blood & 0.46 & 0.024 & $\mathrm{Y}=4.65+0.221 \mathrm{X}$ \\
Zn intake Zn-Zn blood & 0.52 & 0.009 & $\mathrm{Y}=3.695+0.14 \mathrm{X}$ \\
Mg intake-Ca blood & 0.43 & 0.043 & $\mathrm{Y}=24.87+1.101 \mathrm{X}$ \\
Mg intake-Zn blood & 0.52 & 0.009 & $\mathrm{Y}=3.696+0.13 \mathrm{X}$ \\
\hline
\end{tabular}


consumption of Ca. The higher consumption of $\mathrm{Ca}$ increased absorption of Ca. Meanwhile Ca consumption had negative relationship with $\mathrm{Mg}$ absorption due to competition in the digestive tract. So that high $\mathrm{Ca}$ consumption would reduce $\mathrm{Mg}$ absorption. Status of $\mathrm{Ca}$ and $\mathrm{Zn}$ in blood was associated with $\mathrm{Ca}$ consumption. The higher consumption of $\mathrm{Ca}$ increased blood $\mathrm{Ca}$ and $\mathrm{Zn}$ but not increased value of $\mathrm{Ca}$ in semen. Thus, $\mathrm{Cr}$ and Ca status in blood can be used as indicators of the adequacy of $\mathrm{Cr}$ and $\mathrm{Ca}$ in the ration, while $\mathrm{Cr}$ and $\mathrm{Ca}$ in semen does not show $\mathrm{Cr}$ and $\mathrm{Ca}$ in the ration.

\section{Mineral status of Male Sheep Semen and Blood}

Supplementation of $\mathrm{Cr}$ at different levels of $\mathrm{Ca}$ did not affect $\mathrm{Cr}$ status of semen and blood. However, in conditions sufficient rations with $\mathrm{Ca}$ (R3), mean $\mathrm{Cr}$ content of semen was higher than the low-Ca ration (R1). Status of sheep blood $\mathrm{Cr}$ ranged between 0.13 and $0.22 \mathrm{ppm}$. The status of blood $\mathrm{Cr}$ was within the range of normal levels of 0.01 to $0.3 \mathrm{ppm}$ (NRC, 1997). The value of semen $\mathrm{Cr}$ was not affected by $\mathrm{Cr}$ supplementation in the ration and not correlated with the consumption of $\mathrm{Cr}$. This means that the $\mathrm{Cr}$ status of semen was more influenced by other factors, such as antagonism minerals, hormones, vitamins, disease, and stress (NRC, 1997: Watts, 1989).

Status of $\mathrm{Ca}$ in the semen varied from 30.15 to 90.53 ppm (Table 5). This shows that semen Ca balance is not as tight as in the homeostasis of blood minerals. Supplementation of $\mathrm{Cr}$ and decreased DCAB did not affect the status of blood Ca. The levels of blood Ca within the range of 32.19 to 42.05 ppm, means that the Ca status of sheep in marginal conditions. The range of normal blood Ca is 40-60 ppm (Georgievskii et al., 1982). Even though blood $\mathrm{Ca}$ concentration is maintained within narrow limits by calcitonin and parathyroid hormone (suttle, 2010), the levels of blood Ca could reach a value of 112.5 to 118.1 ppm (Ratchford et al., 2001; Stojkovic, 2009). Garut sheep response to Cr supplementation under conditions of high $\mathrm{Ca}$ is expected to be more positive than the low-Ca conditions.
Supplementation of $\mathrm{Cr}$ in the ration did not affect blood Zn of Garut sheep. The concentration of blood $\mathrm{Zn}$ ranged from 5 to $5.45 \mathrm{ppm}$ (Table 5), but still within the normal range 4-6 ppm (Suttle, 2010). Experimental sheep rations containing 139.12 ppm Zn was higher than Zn ration of Ratchford et al. (2001) which contained 43.7 ppm Zn. However Zn Garut sheep blood Zn levels lower than blood $\mathrm{Zn}$ of sheep reported by Ratchford et al. (2001) which was $9.1 \mathrm{ppm}$. Low levels of blood Zn describe, there are many factors that limit the absorption of $\mathrm{Zn}$. Factors that limit the absorption of $\mathrm{Zn}$ and $\mathrm{Zn}$ status in blood is interaction of minerals, adequacy of $\mathrm{Zn}$ in ration, vitamins, and chelating agent (Gropper et al., 2009).

Supplementation of $\mathrm{Cr}$ on ration containing low and sufficient $\mathrm{Ca}$ did not affect the status of blood $\mathrm{Mg}$. The levels of blood $\mathrm{Mg}$ of male Garut sheep ranged from 66.31 to $83.96 \mathrm{ppm}$. The value of blood $\mathrm{Mg}$ of Garut sheep can be categorized high. Ratchford et al. (2001) reported that sheep blood $\mathrm{Mg}$ levels in the range of 22.5 to $23.1 \mathrm{ppm}$, as well as Stojkovic (2009) reported sheep blood Mg levels reached $26.1 \mathrm{ppm}$. High levels of $\mathrm{Mg}$ in the blood was caused by high level of $\mathrm{Mg}$ ration. According to Georgievskii et al. (1982), status of blood $\mathrm{Mg}$ is a function of $\mathrm{Mg}$ content in the ration, the higher $\mathrm{Mg}$ content of the ration will increase blood $\mathrm{Mg}$. This means that under conditions of good status of $\mathrm{Mg}$, blood $\mathrm{Mg}$ levels were not affected by $\mathrm{Cr}$ supplementation.

\section{Nutrient Digestibility of Rations}

Digestibility of dry matter, organic matter, protein, fat, and crude fiber was not affected by $\mathrm{Cr}$ supplementation in rams ration (Table 6). Supplementation of $\mathrm{Cr}$ did not affect digestibility of dry matter and organic matter rations. Supplementation of $\mathrm{Cr}$ did not affect digestion in the rumen and post-rumen. Supplementation of Crpikolinat in sheep rations did not affect body weight gain and number of rumen protozoa (Dallago et al., 2011). Yan et al. (2008) and Yan et al. (2010) stated that providing as much as $0.4 \mathrm{ppm} \mathrm{Cr}$ in sheep ration enhanced growth, improve the utilization of glucose and

Table 5. Means status of Cr, Ca, Zn, dan Mg Garut ram semen and blood (ppm)

\begin{tabular}{|c|c|c|c|c|}
\hline \multirow{2}{*}{ Variables } & \multicolumn{4}{|c|}{ Ration } \\
\hline & R0 & R1 & R2 & R3 \\
\hline \multicolumn{5}{|l|}{ Semen } \\
\hline $\mathrm{Cr}$ & $0.22 \pm \quad 0.02$ & $0.37 \pm 0.14$ & $0.42 \pm \quad 0.28$ & $0.52 \pm 0.36$ \\
\hline $\mathrm{Ca}$ & $70.51 \pm 107.45$ & $30.15 \pm 31.01$ & $92.53 \pm 74.44$ & $50.57 \pm 60.59$ \\
\hline $\mathrm{Zn}$ & $32.87 \pm \quad 6.23$ & $37.26 \pm 6.23$ & $36.77 \pm \quad 6.23$ & $33.15 \pm 6.83$ \\
\hline $\mathrm{Mg}$ & $225.00 \pm 71.00$ & $263.00 \pm 68.00$ & $233.00 \pm 131.00$ & $186.00 \pm 61.00$ \\
\hline \multicolumn{5}{|l|}{ Blood } \\
\hline $\mathrm{Cr}$ & $0.13 \pm \quad 0.06$ & $0.14 \pm 0.06$ & $0.18 \pm \quad 0.07$ & $0.22 \pm 0.06$ \\
\hline $\mathrm{Ca}$ & $37.43 \pm \quad 5.07$ & $32.19 \pm 5.39$ & $39.96 \pm \quad 4.79$ & $42.05 \pm 4.87$ \\
\hline $\mathrm{Zn}$ & $5.00 \pm \quad 0.23$ & $5.15 \pm 0.66$ & $5.45 \pm \quad 0.55$ & $5.35 \pm 0.57$ \\
\hline $\mathrm{Mg}$ & $74.21 \pm 9.27$ & $83.96 \pm 13.62$ & $66.31 \pm 8.45$ & $78.06 \pm 40.05$ \\
\hline
\end{tabular}


Table 6. Means digestibility coefficients of nutrient and digestible energy (DE) of ram ration

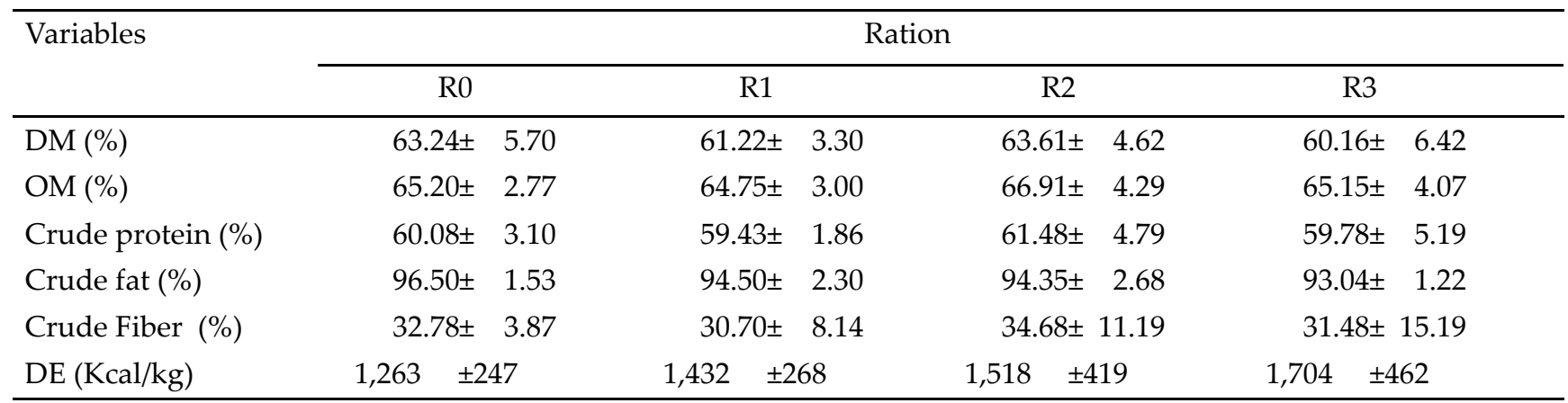

energy metabolism. Mackie et al. (2002) suggested that microbial activity in the digestive tract greatly affected the digestibility. Supplementation of $\mathrm{Cr}$ had little effect on rumen function (Besong et al., 2001). This means that the ration of $\mathrm{Cr}$ supplementation did not affect rumen microbial activity.

\section{CONCLUSION}

Supplementation of $\mathrm{Cr}$ at different levels of $\mathrm{Ca}$ and DCAB in Garut rams rations did not affect feed intake, nutrient digestibility of ration and body weight gain. Supplementation of $\mathrm{Cr}$ reduced absorption of $\mathrm{Cr}$ and $\mathrm{Ca}$ of low-Ca ration. $\mathrm{Cr}$ supplementation did not affect the status of $\mathrm{Cr}, \mathrm{Ca}, \mathrm{Zn}$, and $\mathrm{Mg}$ Garut sheep blood and semen. $\mathrm{Cr}$ consumption had a negative correlation with the absorption of $\mathrm{Cr}$ and positive correlation with $\mathrm{Cr}$ levels in the blood. There is a positive relationship between consumption of $\mathrm{Ca}$ with the absorption of $\mathrm{Ca}$ and $\mathrm{Mg}$ and with $\mathrm{Ca}$ and $\mathrm{Zn}$ levels in the blood. Intake of $\mathrm{Cr}$ and $\mathrm{Ca}$ was not related to the semen $\mathrm{Cr}$ and $\mathrm{Ca}$ levels.

\section{ACKNOWLEDGEMENT}

Authors thank to Directorate General of Higher Education of Republic Indonesia for research grants are awarded through Program Hibah Penelitian Tim Pascasarjana DIPA IPB with the letter of agreement No. 37/13.24.4/SPK/BG-PD/2009 dated March 30, 2009.

\section{REFERENCES}

Agustin, F., T. Toharmat, D. Evvyernie, D. Taniwiryono, S. Tarigan, \& I. Prihantoro. 2010. Inkorporasi kromium oleh fungi Ganoderma lucidum dengan limbah industri kelapa sawit sebagai substrat. Med. Pet. 33: 18-24.

Anderson, R. A. \& A. S. Kozlovsky. 1985. Chromium intake, absorption and excretion of subjects consuming self-selected diets. Am. J. Clin. Nutr. 41: 1177-1183.

Anderson, R. A. \& M. M. Polansky. 1981. Dietary chromium deficiency: Effect on sperm count and fertility in rats. Biol. Trace. Element Res. 3: 1-5.

[AOAC] Association of Official of Analytical Chemist. 2002. Official Methods of Analysis of The Association of Analytical Chemist. 17 $7^{\text {th }}$ Ed. Assoc. Off. Anal. Chem., Arlington.

Astuti, W. D., T. Sutardi, D. Evvyernie, \& T. Toharmat. 2006. Inkorporasi kromium pada khamir dan kapang dengan substrat singkong yang diberi kromium anorganik. Med. Pet. 29: 83-88.
Besong, S., J. A. Jackson, D. S. Trammell, \& V. Akay. 2001. Influence of supplemental chromium on concentrations of liver triglyceride, blood metabolites and rumen VFA profile in steers fed a moderately high fat diet. J. Dairy Sci. 84: 1679-85.

Chan, P. S., J. W. West, J. K. Bernard, \& J. M. Fernandez. 2005 Effects of dietary cation-anion difference on intake, milk yield, and blood components of the early lactation cow. J. Dairy Sci. 88: 4384-4392.

Carry, E. E. \& W. H. Allaway. 1971. Determination of chromium in plants and other biological materials. J. Agric. Food Chem. 19: 1159-1167.

Dallago, B. S. L., C. M. McManus, D. F. Caldeira, A. C. Lopes, T. P. Paima, E. Franco, B. O. Borges, P. H. F. Teles, P. S. Correa, \& H. Louvandini. 2011. Performance and ruminal protozoa in lambs with chromium supplementation. Res. Vet. Sci. 90: 253-256.

Georgievskii, V. I., B. N. Annenkov, \& V. T. Samokhin. 1982. Mineral Nutrition of Animals. Butterworth English.

Gropper, S. S., J. L. Smith, \& J. L. Groff. 2009. Advanced Nutrition and Human Metabolism, Fifth edition. Wadsworth Cengage Learning, Belmont USA. p.513-516

Hidayat, R., T. Toharmat, A. Boediono, \& I. G. Permana. 2009. Manipulasi kondisi fisiologis dan keasaman semen melalui pengaturan perbedaan kation anion ransum dan suplementasi asam lemak pada domba Garut. JITV 14: 25-35.

Kraidees, M. S., L. A. Al-Haidary, S. I. Mufarrej, M. Y. Al-Saiady, H. M. Metwaly, \& M. F. Hussein. 2009. Effect of supplemental chromium levels on performance, digestibility and carcass characteristic of transport-stressed lambs. Asian-Aust. J. Anim. Sci. 22: 1124-1132.

Kumar, S. 2008. Is environmental exposure associated with reproductive health impairments? (Review). J. Turkish-German Gynecol Assoc. 9: 60-69.

Krejpcio, Z. 2001. Essentiality of chromium for human nutrition and health. Polish J. Environmental Studies 10: 399-404.

Lehninger, A. L., D. L. Nelson, \& M. M. Cox. 2004. Principles of Biochemistry 4th edition. WH. Freeman, USA.

Lindemann, M. D., S. D. Carter, L. I. Chiba, C. R. Dove, F. LeMieux, \& L. L. Southernt. 2004. A regional evaluation of chromium tripicolinate supplementation of diets fed to reproducing sows. J. Anim. Sci. 82: 2972-2977.

Luseba, D. 2005. The effect of selenium and chromium on stress level, growth performance selected carcass characteristic and mineral status of feedlot cattle. Thesis. Universitiy of Pretoria Etd.

Mackie, R. I., C. S. McSweeney, \& A. V. Klieve. 2002. Microbial ecology of the ovine rumen. In: M. Freer dan H. Dove (Ed). Sheep Nutrition. CSIRO Plant Industry. Canberra Australia. p. 73-80.

Mathius, I. W, M. Yulistiani, Puastuti, \& Martawidjaya. 2005. Pemanfaatan mineral kromium dalam ransum untuk in- 
duk domba bunting dan laktasi (Utilization of Organic Chromium in The Diet for Pregnant and Lactating Local Ewes). Seminar Peternakan dan Veteriner. p. 422-429.

Mateljan, G. 2010. Chromium. The World's Healthy Food. http://www.whfood.org. [27 Okt 2010].

Mowat, D. N. 2008. Supplemental organic chromium for beef and dairy cattle. University of Guelph, Canada. www.ksu. edu.sa/sites/Colleges/Foods AndAgriculture/AnimalProduction/ Documents/alhaidary\%20i.pdf. [20 Maret 2009]

[NRC] National Research Council. 1985. Nutrient Requirement of Sheep. $6^{\text {th }}$ Revised Ed. Washington DC: National Academic Press.

[NRC] National Research Council. 2001. Nutrient requirements of dairy cattle. $7^{\text {th }}$ revised edition. Washington DC: National Academic Press.

[NRC] National Research Council. 1997. The Role of Chromium in Animal Nutrition. Washington DC: National Academic Press.

[NRC] National Research Council. 2007. Nutrient Requirement of Small Ruminants, sheep, goats, cervids, and new world camelids. Washington DC: National Academic Press.

Pechova, A. \& L. Pavlata. 2007. Chromium as an essential nutrient: a review. Vet. Med. (Praha) 52:1-18.

Pollard, G. V., J. L. Montgomery, T. C. Bramble, K. J. Morrow, C. R. Richardson, S. P. Jackson, \& J. R. Blankton. 2001. Effects of organic chromium on protein synthesis and glucose uptake in ruminants. The Professional Animal Scientist 17:261-266.

Ramberg, C. F., J. D. Ferguson, \& D. T. Galligan. 2009. Metabolic Basis of the Cation Anion Difference Concept DCAD. Center for Animal Health and Productivity University of Pennsylvania. http://130.91.88.59/pc96/ cationanion.html [2 Maret 2009]
Ratchford, W. A., Milliken, K. P. Coffey, E. B. Kegley, \& D. L. Galloway. 2001. Apparent magnesium absorption and retention and serum mineral concentrations in lambs fed different sources of magnesium. The Professional Animal Scientist 17:267-273.

Suttle, N. F. 2010. Mineral Nutrition of Livestock. $4^{\text {th }}$ edition. CAB International, Wallingford. p.453.

Skandhan, K. P., M. T. Makada, \& S. Amit. 2005. Levels of cadmium, chromium, nickel, manganese and lead in normal and pathological human seminal plasma. Urologia 72: 461464.

Stojkovic, J. 2009. The contents of some mineral elements in the blood serum of sheep in different Physiological cycles and with the different level of minerals in a meal. Biotechnology in Animal Husbandry 25: 979-984.

Tauriainen, S. 2001. Dietary cation-anion balance and calcium and magnesium intake of the dry cow. Dissertation. Helsinki: University Of Helsinki, Dept. of Animal Science.

Vincent, J. B. 1999. Mechanisms of Chromium Action : LowMolecular-Weight Chromium-Binding Substance. J. Am. Coll. Nutr. 18: 6 -12.

Yan, X, W. Zhang, J. Cheng, R. Wang, D. O. Kleeman, X. Zhu \& Z. Jia. 2008. Effect of chromium yeast performance, insulin aktivity and lipid metabolism in lamb fed with different dietary protein levels. Asian-Aust. J. Anim. Sci, 21: 853-860.

Yan, X, F. Zhang, D. Li, X. Zhu, \& Z. Jia. 2010. Effect of chromium on energy metabolism in lamb fed with different dietary protein levels. Asian-Aust. J. Anim. Sci. 23: 205-212.

Watts, D. L. 1989. The nutritional relationships of chromium. Journal of Orthomolecular Medicine 4: 17-23. 